\title{
Farmer Groups Enterprises and the Marketing of Staple Food Commodities in Africa
}

\author{
Jonathan Coulter, EU Adviser to the Uganda Commodity \\ Exchange/Warehouse Receipts System, Uganda Commodity Exchange \\ Research Workshop on Collective Action and Market Access for Smallholders \\ October 2-5, 2006 - Cali, Colombia
}

The CGIAR Systemwide Program on Collective Action and Property Rights (CAPRi) is an initiative of the 15 centers that belong to the Consultative Group on International Agricultural Research. The initiative promotes comparative research on the role played by property rights and collective action institutions in shaping the efficiency, sustainability, and equity of natural resource systems. CAPRi's Secretariat is hosted by the International Food Policy Research Institute's (IFPRI) Environment and Production Technology Division (www.ifpri.org).

CAPRi Working Papers contain preliminary material and research results and are circulated prior to a full peer review in order to stimulate discussion and critical comment. It is expected that most Working Papers will eventually be published in some other form, and that their content may also be revised. http://dx.doi.org/10.2499/CAPRiWP72.

Copyright @ August 2007. International Food Policy Research Institute. All rights reserved. Sections of this material may be reproduced for personal and not-for-profit use without the express written permission of but with acknowledgment to IFPRI. To reproduce the material contained herein for profit or commercial use requires express written permission. To obtain permission to reprint, contact the IFPRI Communications Division at ifpri-copyright@cgiar.org.

CGIAR Systemwide Program on Collective Action and Property Rights (CAPRi) c/O INTERNATIONAL FOOD POLICY RESEARCH INSTITUTE

2033 K Street NW, Washington, DC 20006-1002 USA • T +1 202.862.5600 • F +1 202.467.4439 • www.capri.cgiar.org 


\section{ACKNOWLEDGEMENTS}

The author wishes to thank the APEP and ASPS Projects, and the Uganda Cooperative Alliance, for their assistance with information and in arranging field visits in Uganda. 


\begin{abstract}
There are some apparently successful cases of collective marketing with staple food commodities (grains and root crops), but these are less common than cases involving higher value agricultural products. These can be attributed to the benefit/cost ratio to participants being generally higher for collective marketing of the higher-value crops. Some of the costs are 'hidden', in the sense that they are borne by individuals in time spent in attending meetings, and not shown in the financial statements of the enterprises concerned.

Examining a series of cases, the paper advocates an approach to the marketing of staples which involves analyzing the value chain and identifying those activities which on the one hand, best lend themselves to individual initiative, and those where on the other hand, group approaches are more likely to prosper. Dual purpose food marketing involving village storage in anticipation of both external market opportunities and local lean season shortages usually falls into the former category. Collective initiatives have a higher probability of success when they complement agricultural intensification and involve bulking substantial quantities of produce for qualityconscious commercial buyers. Prospects for successful collective marketing are moreover greater where there is a history of collective endeavor, where focused on simple activities like bulking and distribution of inputs, where primary groups are small and homogenous in terms of interests and objectives, where they can establish lasting relationships with strong trade counterparties, where supported by effective training (especially re attitudes, numeracy, and business skills), where they can access effectively managed storage and inventory credit services, and where there is framework of law enforcement.

The immediate poverty alleviation and programmatic priorities of funding agencies often undermine the effectiveness of promotional activities in support of collective marketing. This problem may be addressed by instituting systems of independent review and peer review processes, and involving open discussion of pros and cons of individual and collective approaches.
\end{abstract}

Keywords: collective marketing, producer organization, staple food, village storage, inventory credit, microfinance, disbursement-driven 


\section{TABLE OF CONTENTS}

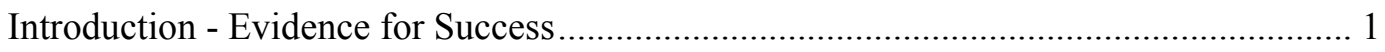

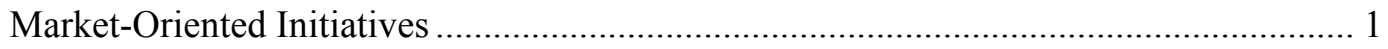

Dual Purpose Initiatives Concerned with Markets and Local Food Security....................11

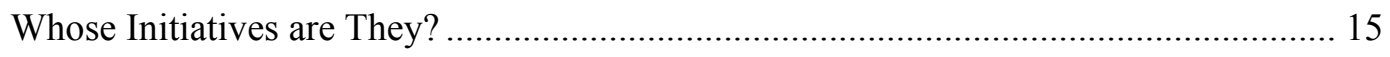

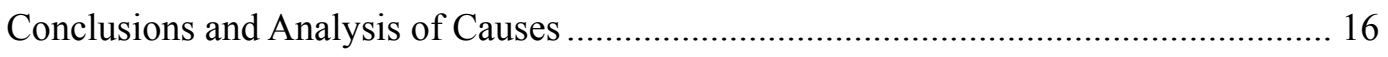

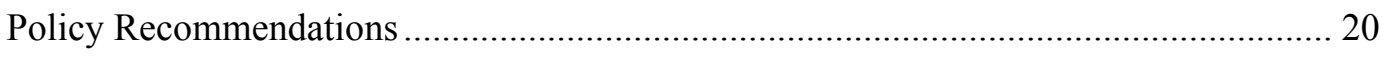

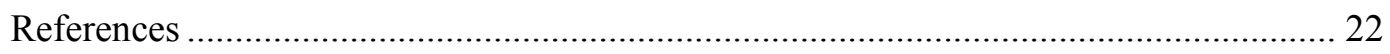




\title{
Farmer Groups Enterprises and the Marketing of Staple Food Commodities in Africa
}

\author{
Jonathan Coulter ${ }^{1}$
}

\section{INTRODUCTION - EVIDENCE FOR SUCCESS}

This paper compares the case of staple food crops, which consist for the most part of cereals and root crops, with higher value crops and products such as cotton, cocoa, oilseeds, dried fruit, spices and seeds, in Africa. By and large, collective marketing and processing initiatives are more successful with the latter than the former. This is immediately apparent from a systematic study of collective marketing initiatives in five African countries that the Natural Resources Institute and the Plunkett Foundation carried out in the 1990s (Stringfellow et al. 1997). The research team identified 16 relatively successful cases on the basis of prima facie evidence, but only two were concerned with staple food crops. Both of these were dry cereals (sorghum and rice) rather than the more bulky staples such as cassava or bananas.

\section{MARKET-ORIENTED INITIATIVES}

\section{Francophone Experience}

Francophone Africa has seen some of the most notable achievements with collective marketing. Starting in Mali in 1974, 'Associations Villageoises' (AVs) and similar producer organizations (POs) became a major component of contract-farming systems in the burgeoning parastatally-controlled cotton sectors of francophone countries. The parastatals were able to devolve much of the responsibility for input and equipment supplies and primary marketing of seed cotton

\footnotetext{
${ }^{1}$ EU Adviser to the Uganda Commodity Exchange/Warehouse Receipts System, Uganda Commodity Exchange, Social Security House (former Udyam House) 1st Floor, Plot 4, Jinja Road, P.O. Box 22
} 
down to these all-village institutions in a mutually beneficial manner. The AVs worked in a linkagedependent relationship with the parastatal cotton companies which oversaw their operation and had a vested interest in their survival (Coulter and Tyler 1992; Bingen 1998).

Mali and other francophone countries have also witnessed large numbers of producer organizations (AVs and 'groupements') being organized in conjunction with irrigated rice schemes. While often playing an important role in service provision, they have encountered many problems. The author visited the leading West African irrigation scheme, the Office du Niger in Mali, twice in the early 1990s (Coulter and Tyler 1992), and again in 2005, when carrying out a consultancy assignment for the European Commission. In both cases he found that POs were experiencing serious governance and management problems. In 2005, farmers were largely by-passing them in favor of other support mechanisms, including micro-finance institutions and money-lenders. One knowledgeable commentator estimated that only 2 percent of all POs working in the zone were operating correctly; most of the others were highly indebted and technically bankrupt.

In the neighboring country, Niger, Henri Chunleau, the Co-Director of the PAFRIZ Rice Support Programme expressed misgivings about indiscriminately establishing cooperatives in rice schemes, given their lack of coherence with pre-existing hierarchical social structures. Funding agencies had in his view paid insufficient attention to this issue, and the weak performance of the cooperatives was largely responsible for having to rehabilitate schemes after 20 years. The cooperatives had many difficulties: a lack of clarity concerning ownership of land and equipment: poor water management, land preparation and cultural practices; poor management of working capital leading to mounting debt and inadequate input supplies; a mixture of varieties adversely affecting the quality of milled rice; and early sales of milled rice. In view of these problems, PAFRIZ was providing intense support to a group of ten of the more successful schemes, covering a total of 2,000 ha, through the establishment of a business services centre (CPS) with the aim of enabling farmers to provide the services they needed. Groups were also being formed around specific activities such as production of seedlings and mechanization. Related to his misgivings about the cooperative model, Chunleau felt that private investors should participate in the development of the remaining 200,000 ha of Niger which was suitable for irrigated rice. $^{2}$

\footnotetext{
${ }^{2}$ Source: Interview with the author in September 2005, during EC Monitoring of CGIAR Projects funded by the European Community
} 


\section{Experiences from Mozambique, Malawi, Tanzania and Ghana}

In various parts of Mozambique, collective marketing has been organized along somewhat similar lines to francophone Africa. However, the commercial partners are not parastatals, but private cotton and tobacco companies operating as monopsonists within officially sanctioned geographic concessions. The primary organizations are voluntary groupings of typically 30 members, often called 'Rural Group Enterprises' (or RGEs), promoted by NGOs specialized in agricultural development. As in Francophone countries, most of the successful collective marketing has been associated with cash crops. 
Table 1. Evidence for success of collective marketing with staple vis-à-vis higher value crops in Africa

\begin{tabular}{|c|c|c|}
\hline \multicolumn{2}{|c|}{$\begin{array}{l}\text { Case } \quad \text { Evidence } \\
\text { Market-oriented initiatives }\end{array}$} & Source \\
\hline Ghana, 1995 & $\begin{array}{l}\text { Three 'successful' cases were in cocoa financing (in } \\
\text { conjunction with Barclays Bank), seed (for maize and } \\
\text { cowpeas), and oil palm }\end{array}$ & \multirow{4}{*}{ Stringfellow et al. 1997} \\
\hline Uganda, 1996 & $\begin{array}{l}\text { Five 'successful' cases were in coffee, coffee/beans, } \\
\text { vanilla, dried fruit (2) and bean seed }\end{array}$ & \\
\hline Zimbabwe, 1996 & $\begin{array}{l}\text { Two 'successful' cases were in seed supplies (millet and } \\
\text { sorghum), and sorghum grain (for Chibuku breweries) }\end{array}$ & \\
\hline $\begin{array}{l}\text { Mali/Burkina Faso, } \\
1996\end{array}$ & $\begin{array}{l}\text { Six 'successful' cases, of which two were mainly } \\
\text { concerned with cotton, one with rice, one with shea butter } \\
\text { soap production, and two with mango drying }\end{array}$ & \\
\hline Ghana & $\begin{array}{l}\text { Inventory credit project with cooperatives - brought major } \\
\text { benefits to participating farmers, but at high supervisory } \\
\text { cost; could not be spun off. }\end{array}$ & $\begin{array}{l}\text { Coulter and Shepherd } \\
1995\end{array}$ \\
\hline Francophone Africa & $\begin{array}{l}\text { Parastatally-marketed cotton, not staple food products, has } \\
\text { been the major driver of producer organization }\end{array}$ & Bingen 1998 \\
\hline Tanzania & $\begin{array}{l}\text { Rapid demise of cooperative activity with cereals with the } \\
\text { onset of liberalization, contrasts with slower decline in } \\
\text { case of some other crops, notably coffee }\end{array}$ & Coulter and Golob 1992 \\
\hline Malawi & $\begin{array}{l}\text { Farmers' clubs contributed to the intensification of maize } \\
\text { under parastatally-controlled system of } 1970 \mathrm{~s} \text { and } 1980 \mathrm{~s} \text {, } \\
\text { but failed in liberalized regime of } 1990 \mathrm{~s} \text {; they now focus } \\
\text { on cotton, tobacco and other higher value crops }\end{array}$ & Chirwa et al. (2005) \\
\hline Mozambique & $\begin{array}{l}\text { Tobacco and cotton within concession regimes overtake } \\
\text { maize as leading crops for collective marketing }\end{array}$ & Coulter 2006 \\
\hline Uganda & $\begin{array}{l}\text { Cereals account for around } 38 \% \text { by weight of } \\
\text { commodities sold by POs supported by the APEP Project } \\
\text { and the Uganda Cooperative Alliance. Some highly } \\
\text { successful marketing of cereals noted, partly in response } \\
\text { to World Food Programme's demand for relatively high } \\
\text { quality maize and beans. }\end{array}$ & $\begin{array}{l}\text { Author's findings } \\
\text { during present } \\
\text { employment }\end{array}$ \\
\hline
\end{tabular}

\section{Dual purpose initiatives: local food security and surplus marketing}

\begin{tabular}{lll}
\hline Francophone Africa & $\begin{array}{l}\text { The major initiative with cereals has been Cereal Banks, } \\
\text { at least 3,300 promoted since the early 70s with low level } \\
\text { of survival }\end{array}$ & $\begin{array}{l}\text { Günther and Mück } \\
1995\end{array}$ \\
Kenya & $\begin{array}{l}\text { Kenyan cereals banks founded since 2002 experiencing } \\
\text { similar difficulties }\end{array}$ & Coulter 2006 \\
Tanzania & $\begin{array}{l}\text { Village stores constructed under Rural Structures Project } \\
\text { by-passed by emerging private trade }\end{array}$ & Coulter and Golob 1992 \\
$\begin{array}{l}\text { Central America and } \\
\text { Swaziland }\end{array}$ & $\begin{array}{l}\text { Successful initiatives involving household storage in small } \\
\text { metal silos }\end{array}$ & $\begin{array}{l}\text { Coulter et al. 1995; } \\
\text { Bideaux et al. 2002 }\end{array}$ \\
Madagascar & $\begin{array}{l}\text { Village Community Granaries scheme for rice achieves } \\
\text { success, combining individual initiative and microfinance }\end{array}$ & Fraslin 2004 and 2005 \\
\hline
\end{tabular}


In Malawi, Chirwa et al. (2005) show how the parastatal Agricultural Development and Marketing Corporation (ADMARC) worked with smallholder 'farmer clubs' in the 1970s and 1980s to achieve considerable success, particularly in regards to the staple food crop, maize. Farmer clubs were beneficiaries of production credits which they repaid by delivering products to ADMARC. However, the system largely collapsed after ADMARC lost its monopoly of maize procurement and could no longer ensure that clubs repaid their input credits. Significantly, some clubs which grow cotton have survived, and some new ones have been established to take advantage of a policy change which allowed smallholder farmers to grow burley tobacco.

Tanzania's experience with market liberalization in the 80 s and 90 s provides further evidence of the relative unattractiveness of collective marketing with staple crops. Generally speaking, private traders encroached on the cereals trade earlier than they did on the trade in cash crops such as cotton and coffee. Cooperative Unions remain significant players in the coffee sector to this day, whereas their exit from cereal markets started during the 1980s. At the time this was happening, donors were busily funding the construction of primary society stores under the 'Rural Structures Programme', with the understanding that primary societies would use these to hold surplus production. A total of around 1,000 stores of circa 300 tonnes capacity were eventually built, and until the early $90 \mathrm{~s}$, the Government of Tanzania was committed to providing such stores for the majority of villages in the country. In practice, however, farmers preferred to store their surplus grain at their homes rather than entrust it to their local primary societies, and the majority of these stores have remain unutilized to this day (Coulter and Golob 1992; Coulter and Schneider 2004).

Recently, the Government of Tanzania has been seeking to put these stores to use by placing them under the control of collateral management companies which can grade the commodities and guarantee safe storage. By making use of these empty stores, this approach can potentially give a new lease of life to the collective marketing of grains and other commodities. Producer groups can deposit commodities in the warehouses and use inventory credit so as to sell at a time of their own choosing. Indeed, the system of coffee warehouse receipts in Tanzania and grain warehouse receipts in Zambia already show producer groups responding positively to this incentive (Coulter 2005). Village stores can be used to store food for local consumption, and for this reason the Tanzanian case is also relevant to the section of this paper dealing with 'dual purpose initiatives.'

In the late 1980s TechnoServe, an NGO, devised a scheme whereby Ghanaian farmers organized into village cooperatives could obtain inventory credit from banks against the stocks. TechnoServe adopted a businesslike approach and provided the cooperatives with technical and accounting assistance in order to manage the operation. Small farmers gained greatly, and loan 
repayment ranged between 95 and 100 percent. However, the volumes cooperatives collectively handled were limited - usually around 300 tonnes per annum, and with a peak of 1,100 tonnes - and the cooperatives continued relying on the NGO to supervise storage operations, monitor cooperative records and activities and act as the bank's unpaid agent, and ensure loan repayment. Consequently, the system did not reach a scale at which it could cover all the related costs and provide comfort to the banks without the mediation of the NGO. This sustainability problem may be partly attributed to local circumstances in Ghana: commercial banks were weakly represented in rural areas, had limited interest in agriculture, and could obtain substantial risk-free returns by investing in Treasury Bills. However, there appears to have been some problem with the cooperative-controlled storage model itself. While members earned high returns from inventory credit, the cooperatives were unable or unwilling to break free from external support and become self-sustaining entities (Coulter and Shepherd 1995; Kwadjo 2000).

In the case of francophone Africa and Mozambique, one might argue that the success of collective marketing with cotton and tobacco derives from governments instituting single channel systems, or zonal monopsonies, rather than these crops having any inherent advantages for producer groups. However, here it should be noted that while in some parts of Africa single-channel or monopsonistic systems remain an option with export crops, this is no longer the case with staple foods. Single-channel marketing systems were en vogue with staple crops in the immediate postcolonial period, but with the growth of informal trading systems, they became practically unenforceable. These commodities are readily consumable and can be sold to thousands of potential customers; hence, any attempt to enforce a single-channel system is prone to establish a vibrant but illegal 'parallel trade.'

\section{Recent Experience in Uganda}

The author is presently working in Uganda, where in June 2006 he collected information on producer marketing organizations in nine districts. Most of these were working under the auspices of two leading technical assistance programs, notably the Agricultural Productivity Enhancement Program (APEP) and the Uganda Cooperative Alliance (UCA). The cooperative movement experienced collapse following the market liberalization that took place in the early 1990s, but these programs have sought to give new life to the collective marketing concept. The groups visited were not a random selection, but a purposeful choice of those which these agencies considered to have worked well. 
Both UCA and APEP involve primary level POs producing and bulking up produce for second-tier bodies which carry out a brokerage function on behalf of the primary level organizations. There are many similarities between these two promoters' approaches, but this paper focuses mainly on APEP (see also Ferris 2006).

Up to 2004, APEP (or rather its predecessor, the IDEA Project) supported production with numerous on-farm demonstrations, and encouraged private sector buyers ('corporates') to engage with farmers for input supply and marketing. Since 2004, APEP has added a marketing component managed by the Cooperative League of the United States (CLUSA), in which farmers organize into small producer organizations (POs), each with 20-30 members. Each PO has a small executive (3-4 persons) and two 'lead farmers' who are responsible for hosting the demonstrations, extending technical knowledge to fellow group members, and estimating marketed volumes. About ten POs form a 'Depot Committee' which is responsible for finding a market for members' produce - see Figure 1. Depending on the crop, depot committees either deal with a range of competitive buyers or enter a longer-term relationship with a particular buyer who provides advantageous terms. 
Figure 1. APEP / CLUSA model for farmer organization and corporate market chain linkage

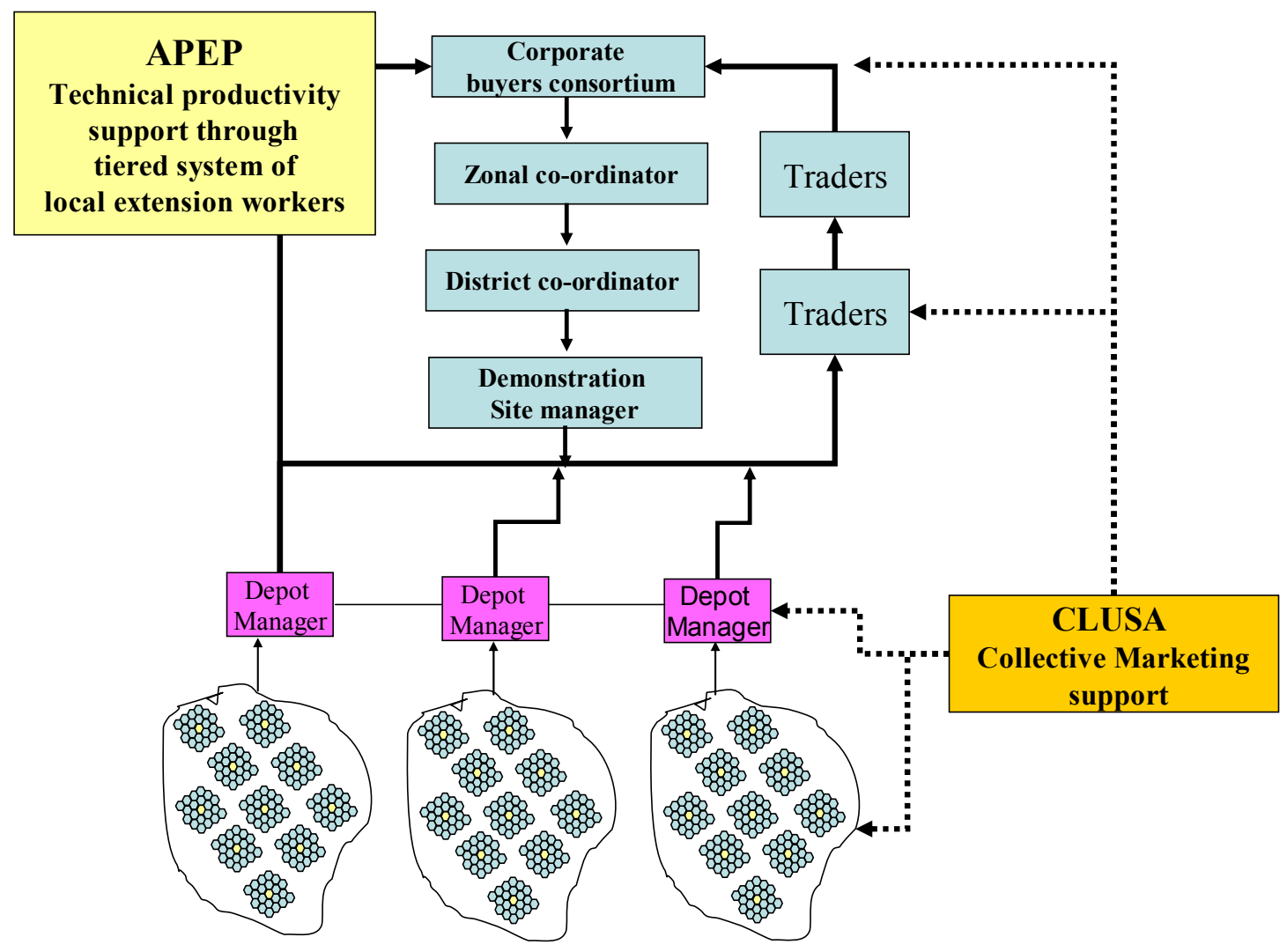

Source: Ferris 2006

APEP has a support structure that interacts with the POs and Depot Committees. The demonstrations are managed by a 'site manager' who is paid a fee of US\$5 per successful demonstration and has a target of at least 15 per season. Numerical data suggests that both the APEP and the UCA-backed groups are having significant impact with staple crops, though this must be partly attributed to the purchasing activity of the World Food Programme (WFP), which is helping establish a market for maize of higher quality than that normally demanded by other end users in Uganda (see Box 1). 


\section{BOX 1. Collective bulking of crops in Uganda}

Statistics for 2005 show that POs supported by APEP and primary societies belonging to Area Marketing Cooperatives supported by UCA altogether bulked 20,872 tonnes of commodities and that staple commodities (maize, beans and rice) constituted $38 \%$ by weight, followed by coffee $(25 \%)$, sunflower $(15 \%)$, seed cotton $(11 \%)$, malting barley $(5 \%)$ and potatoes $(4 \%)$. All farmer groups reported the bulking of staple crops to be a profitable activity, and in Eastern Uganda groups mentioned farmers realizing profits ranging from $\$ 16$ to $\$ 99$ per tonne in recent harvests. However, it should be remembered here that the groups visited were those that UCA and APEP considered to have performed more successfully.

The purchases of the World Food Programme (WFP), which was supplying food to the internally displaced population in northern Uganda and to people in other parts of the Great Lakes region, was one of the main factors driving the demand for maize. Total WFP purchases of maize and maize meal in 2005 were 123,000 and 18,000 tonnes respectively, accounting for about one quarter of estimated national production of this crop. WFP has been trying to apply official East African standards for maize which are far in excess of the quality requirements expressed by most of the trade. This has made it more advantageous for POs to organize so as to ensure quality at origin, notably by having it mechanically shelled, eliminating diseased grain and foreign matter, and drying it properly using tarpaulins or drying cribs.

Since 2004, the number of APEP-supported groups have grown spectacularly, and by March 2006 there were 1,284 POs working through 156 depot committees. While some of this can be attributed to previous projects in support of producer organizations, the growth is largely due to strengths in APEP's conceptual approach. These are as follows:

- there was a simultaneous and mutually reinforcing focus on intensification and marketing; by improving their marketing arrangements, farmers obtain greater revenue for their outputs and improve their access to inputs, thereby facilitating the process of intensification;

- the primary units have only 20-30 members, which stands in contrast to groups of up to 200 members under the previous IDEA project and the policy of more or less unlimited membership with traditional primary cooperative societies - research literature supports this new approach on the grounds that it enhances group cohesion and sustainability (see Stringfellow et al. 1997);

- the internal structure is such as to encourage accountability and facilitate communications; individual lead farmers have specific responsibilities and must keep in regular touch with 10 to 15 other farmers;

- APEP has engaged the 'corporate' buyers, encouraging these to invest in the supply chain and encouraging farmers to produce and organize in response to demand;

- a strict policy of avoiding handouts, beyond resources provided for demonstrations, which encourages farmers to value the POs as vehicles for group action and self-help rather than as conduits for donated resources; and 
- not encouraging farmers to form top-heavy federative structures - farmers may cooperate beyond the 'depot committee' level but must do so entirely at their own discretion and expense.

While this recent experience is encouraging, the history of collective marketing initiatives suggests that there are considerable hazards. Some knowledgeable commentators point to a lack of integrity among leaders of producer organizations and the failure of the wider society to hold them accountable for misdeeds. A recent example of this is the collapse of an important maize marketing project in Eastern Uganda. APEP's report on activities to March 2006 alludes to the risk that good governance and transparency fall victim to the "Big Man" syndrome in which a successful DC is hijacked either by local politicians or so called strong men within their ranks. This comment echoes Isiaho (2005) who, commenting upon cooperatives in neighboring Kenya, stated that a large percentage of cooperative leaders use their positions as launching pads for entering politics.

In practice, maintaining a policy of avoiding handouts is likely to prove particularly challenging, given the proliferation of rural development initiatives in Uganda, many of which offer free or subsidized inputs. In view of the worldwide level of agricultural subsidies, the latter may be seen as entirely justifiable. However, when subsidies are associated with group formation they may result in a membership that values them above what the group can deliver through cooperative enterprise, and thereby weaken the group at the moment of its inception. The problems of recruiting non-performing members are vividly illustrated by the experience of the Kiboroa Self-Help Group which was assisted by a USAID project in Western Kenya. When the project started, the group quickly signed up 150 farmers, but when it became apparent that KMDP would not be providing hand-outs, the number fell to 20; since then membership has risen to 100 of which 60 were 'active,' and the group has equity of about US\$7,000 (Coulter 2006).

Another challenge is the lack of applied numeracy. During field visit in Uganda, the author found that in five out of nine districts, officers and staff of producer organizations engaged in bulking of products did not have key data and/or they lacked the ability to compare revenues and costs. This suggests that organizations supporting collective marketing initiatives need to invest more in training in this area.

Ugandan cooperatives largely collapsed in the 1990s as they failed to compete in the new liberalized policy environment ushered in by reforms undertaken at the beginning of the decade. Despite this, support for collective marketing remains a favorite activity for donors who see a continuing need for cooperative ventures, and believe that new or reformed structures will offer more effective business entities and will be more accountable to members' interests. The new initiatives have resulted in an overlay of organizational types and some duplication of activity, with different structures co-existing side by side. In some cases however, local POs seem to have successfully 
absorbed new donor initiatives into their existing structures. There are also many cases in Uganda as in other African countries where POs have become excessively dependent on donors or local NGOs for material support or information.

\section{DUAL PURPOSE INITIATIVES CONCERNED WITH MARKETS AND LOCAL FOOD SECURITY}

\section{The Cereal Banks story}

Cereal banks are the best known POs concerned with staple foods in Sahelian countries. Thousands were organized under the auspices of NGOs and development projects in the wake of famines in the 1970s and 1980s3. The objectives were to prevent farmers from 'over-selling' at low prices and then buying back at high prices, to avoid exploitation by middlemen and help surplusproducing farmers to find a better market for their grain. In the main part they have proved institutionally unsustainable, tending to progressively decapitalize and disappear once outside support is removed. Drawing upon a range of sources (Gergely et al. 1990; Berg and Kent 1991; Günther and Mück 1995; CRS 1998, and; Reusse 2002), one can attribute the poor performance to difficulties in competing with private trade in 'spatial arbitrage' (trading between geographic locations), frequent losses from 'temporal arbitrage' (speculative storage), providing credits in the lean season to members who do not repay, management errors (due to a mixture of inexperience, slow collective decision-making, and social pressures) and corruption.

CBs were particularly vulnerable to these problems because of the heterogeneous nature of their membership, including surplus producing members, deficit producing members and nonproducers, and having objectives that cover both business and social functions. As such CB membership tends to lack a single-minded focus for its activity. Part of the problem should also be attributed to the promoting entities' limited time horizon and charitable outlook. In this regard, Günther and Mück (1995) noted that the support these entities provided during a 20 year period never included an external audit.

\footnotetext{
${ }^{3}$ Günther and Mück (1995, p2) quote FAO research showing that over 15 years 3,300 CBs were supported in 10 countries at a cost in terms of subsidies of US\$30 million.
} 
Since 2002, an international agency attempted to introduce the cereal banks model into Kenya, through four cooperating NGOs. The author reviewed progress in a consultancy assignment, but found that it was poor. CBs were showing similar weaknesses to those of West Africa, and could not be considered a sustainable form of business enterprise. In particular, they had difficulty competing in spatial arbitrage, and there was evidence of accumulating consumer debt, slow collective decision-making, corruption and decapitalization. Where decapitalization was being avoided, it required an unsustainable level of external supervision.

\section{Individual Storage Initiatives}

The Central American initiative relates to a smallholder maize dominated agricultural system which bears similarities to much of southern and eastern Africa. Swiss Development Cooperation (SDC) supported the initiative for around 22 years, working with national implementing agencies in each country, and when it finally withdrew farmers in four countries had acquired between 400,000 and 500,000 silos of average $800 \mathrm{~kg}$ capacity (pers. comm., SDC). A large percentage of the silos were sold for cash at a price which covered the artisans' full cost, a part was sold for credit, a part was subsidized, and some were donated by the transfer institutions. The last evaluation mission (Bidaux et al. 2002) estimated that 40 percent of silos were sold at a subsidized price.

However information collected earlier through a series of focus-group interviews by Coulter, Brussel et al. (1995) suggest that the silos would have been a major marketing success without subsidy, because they provided farmers with overwhelming food security and commercial advantages, and a range of secondary benefits (see Box 2). 


\section{Box 2. Benefits from individual farmer storage of maize using galvanized iron silos in Central America}

Food security provided the key motive for rural families to acquire these silos, which typically of capacity of 0.82 tonnes each. The impact on household food security was particularly large in the lean season when farmers had more and better quality food available. There was a large reduction in post-harvest losses, and farmers no longer found themselves obliged to sell grain preventively to avoid losses due to pests. They could keep it for their own consumption in the lean season. Those farmers who did not own a silo and needed to acquire food in the lean season could do so at lower cost, since instead of going to middlemen in local trading centers, they could buy from neighbors who had acquired silos and had surpluses to sell.

Some farmers acquired two or more silos and used them as part of the marketing strategy. Given pronounced seasonal price trends, they increased their income by selling grain at a later date. There were also favorable knock-on effects on production. On the one hand, the silo favored the production of hybrid maize varieties that were highly susceptible to insect damage. On the other hand, Guatemalan farmers also derived benefit through crop diversification. They indicated that savings in the amount of grain stored in the silo allowed them to cultivate more coffee, bananas, and vegetables.

Except in native-American communities in Guatemala, women were found to administer the silo, and this gave them greater control over the household food supply and greater ability to deal with shortages. Moreover, the use of silos reduced female drudgery (in shelling cobs, cleaning), which resulted in greater hygiene in the home and was perceived to contribute to better health due to the absence of contamination by rodents, insects, and feces, as well as contact insecticides previously used to preserve grain.

Another important advantage of the silo was the convenience factor. Despite the poverty of most farmers, the simplicity of the structure was a major attraction. It could be purchased "ready to use", without the need for the farmer to find the materials him/herself; it did not require much maintenance and was easy to use.

The silos contributed to price stabilization at national and regional level. Farmers held part of their grain as a precautionary reserve in case the next crop turned out to be poor. Once they knew the crop was ripening satisfactorily, they would sell the surplus and thereby put a damper on lean season prices.

Source: Coulter, Brussel and Wright 1995. The authors carried out an evaluation covering Honduras, Guatemala, El Salvador and Nicaragua. The work involved desk research, interviews with key informants and 42 focus groups in 14 communities spread throughout the four participating countries. In each community separate interviews were held with groups of male silo owners, women silo owners, and a control group of non silo owners.

The success of the silos is also a consequence of the promoters' systematic and thorough approach to the development and marketing of silos. For example, they ascertained acceptability of alternative storage structures through concept tests and pilots. They standardized silo design so as to simplify marketing and facilitate larger scale production and quality control. They helped local artisans become entrepreneurs, producing, selling, and providing after-sales service. NGOs became an integral part of the marketing supply chain, with agreements specifying respective responsibilities 
of the NGO and the project. When SDC ended its support, it did so in the confidence that artisans would continue producing high-quality silos to satisfy the demand of small farmers and others.

In Swaziland, farmers started using silos made of corrugated sheets to store maize in the 1960s. They normally use them in conjunction with drying cribs, which they use to dry the grain before shelling and storage. The level of adoption of the silo is very high, as much as 10 units for every 100 head of population, vis à vis an average of 1.5/100 in four Central American countries; this is somewhat surprising, given that the cost of silos was lower and the quality control over their fabrication and usage superior in Central America. It appears that adoption has been spurred by the public incentive framework for maize production, which allowed most farmers to produce substantial quantities, as well as farming families investing remittances from South Africa to acquire the silo (Coulter and Schneider 2004).

In 2000, the Catholic Diocese of Homa Bay started to introduce the silo of Central American design into Western Kenya, and by the end of 2005, some 500 units had been sold. Demand was increasing, despite the absence of subsidy. The user profile was very different to Central America and Swaziland, since half the silos produced (these being the larger units) was acquired by institutions, mostly schools, rather than rural households (Coulter 2006).

When these experiences with small metal silos are contrasted with cereal banks and collective storage initiatives such as Tanzanian Rural Structures Programme, they suggest that in the case of dual purpose initiatives, more can be achieved through individual than collective action.

\section{Madagascar: The Village Community Graneries (GCV) Scheme}

The scheme involves farmers who produce rice and other agricultural commodities on small plots, mainly for home and local consumption. The scheme started in the early 90s, and by 2003 involved 27,000 small farmers holding 80,000 tonnes of paddy in stores with capacity ranging from 5 to 120 tonnes each. Fraslin (2005) claims that by enabling farmers to store longer, it has provided them with a financial surplus equivalent to a 50 percent increase in paddy yield, as well as contributing to the stabilization of prices regionally.

The scheme was set up by a large network of village-based credit unions (the 'Caisses d'Epargne et de Crédit Agricole Mutuels', or CECAM), which enjoyed the assistance of an NGO, various French agricultural unions, European cooperative bankers (Rabobank and Crédit Agricole Mutuel) and several donors. According to Fraslin (2004), a key to this achievement was the members' subscription of substantial equity capital, which at once committed them to the Endeavour, and helped in obtaining soft loan funding from the public treasury. The network expected to break even by 
2006. The CECAMs provide members with inventory credit along with seasonal production credit, leasing, and other credit products, and there is also a more modest savings facility. Together with its regional federation (URECAM), they also provide a complete supervisory structure for ensuring correct storage protocols and the integrity of the inventory credit system.

This experience shows that it is possible to organize sound village-based inventory credit systems within a strong movement of rural credit unions or rural banks. However, it has to be recognized that most African countries do not have such large or robust member-owned rural savings and credit organizations, and this makes it more difficult to achieve the same result. Uganda is a case in point. A major review of agricultural finance in Uganda found that there were hundreds of SACCOs and other member-owned financial organizations, but that "they were among the weakest and least sustainable of the financial institutions" in that country, and that "they had not been able to significantly improve their financial position in spite of heavy donor support” (Meyer et al. 2004). Government is currently seeking to develop rural finance through its 'Bona Bagagawale' (Wealth for All) program of support to microfinance institutions, but it will take some time to see whether this is effective.

\section{WHOSE INITIATIVES ARE THEY?}

Some analysts have highlighted the value of farmers organizing their own initiatives, rather than their being promoted by outsiders, such as donors or NGOs. The early history of cooperatives provides some weight to this argument, in that the first successful model, involving consumer cooperatives in the UK, emerged from the spontaneous efforts of flannel weavers without the involvement of any of the well-to-do philanthropists who promoted cooperative initiatives among working class people in the early $19^{\text {th }}$ Century.

However, there is a difficulty with this argument in contemporary Africa. Unlike the case in early to mid- $19^{\text {th }}$ Century Europe, there are many public and private organizations seeking to promote collective marketing among rural people. Collective marketing may start through the spontaneous efforts of individual farmers, but initiatives with prospects for success generally attract the eye of outside organizations, and their assistance is more often accepted than not. One cannot deny the importance of local ownership, but it is almost inevitable under current circumstances that outsiders will get involved in one way or another.

Farmer Field Schools, discussed by Okoth et al. (2006) for Uganda, offer farmers a way of learning to work together to solve agronomic and other problems, before making larger financial commitments to collective marketing enterprises. They give farmers time to work out what is in their 
best interests and build social capital to undertake such initiatives. However it is worth noting that these producer organizations, in common with others, receive outside support and grants. Moreover, as soon as they wish to grow beyond the 'school' and 'pilot' stages and become commercial enterprises in their own right, economies of scale become an issue. This means that they tend to need standardized federative structure covering many communities and technical assistance packages that are modularized to the structure. There is a limit to which one can economically tailor technical assistance to the need of each individual PO. This inevitably results in a process of negotiation with outside service suppliers - projects, NGOs and companies - whereby the group gives away some of its local autonomy in exchange for external support. However home-grown or indigenous POs are at origin, they grow up in the era of development cooperation, and they respond to the (often competing) offers of outside service providers and funding agencies. The quality of the service of these latter agencies is therefore one of the keys to their success.

At the same time, some PO initiatives that are apparently formulaic and NGO-driven may engender considerable sense of ownership among members, because the NGO concerned has invested time in understanding problems up front and reviewing previous initiatives, and because their formulae incorporate certain principles and practices which have stood the test of time. An example of the latter may be, as in the APEP case above, telling farmers they need to invest their own resources in the business rather than expecting outsiders to put up the money. Such hard decisions tend to concentrate members' minds as to whether the enterprise is really theirs or simply an outside implant of which they can take advantage for a time.

In conclusion then, we feel local ownership is of the greatest importance, but that it is unrealistic under present circumstances to argue in terms of idealized organizations created purely from the bottom up. Moreover it is right to focus on the role of outside promoters and financiers, since they are to a major extent those 'who pay the piper.'

\section{CONCLUSIONS AND ANALYSIS OF CAUSES}

The evidence presented above shows that while collective marketing is proving successful with staple crops in some cases, it has generally been more difficult than with higher value cash crops. It is probable that the explanation lies in differences in the benefits and costs of cooperation for higher and lower value crops respectively.

Here it is important to recognize that the act of cooperating with one's neighbors involves considerable 'hidden' costs of a kind that are not usually reflected in group profit and loss accounts, including: 
- Costs that individuals incur from loss of autonomy within the group - to buy and sell produce of any quality, to whom they want and when they want;

- The opportunity cost of time spent in meetings and communications with other group members;

- Costs of enforcing agreed behavior on officers, staff and other group members, including the settlement of disputes and the application of sanctions. 'Agreed behavior' may for example involve protocols for spraying, the rejection of produce which does not meet specified standards, or a ban on 'side-selling' of produce in contempt of contractual commitments to buyers which have provided services, inputs, and/or credit.

The greater the added value per unit of collective, as opposed to individual, effort, the easier it is for producers to bear the above costs, and the more likely it is that they will wish to cooperate together. Cash crops do not always provide high returns to effort, but some of the cases cited in Table 1 (e.g. vanilla, dried fruit and seeds) concern situations where niche markets and premium prices have provided producers with a strong incentive to get organized.

At the same time, the lower the 'hidden' costs are, the more likely it is that producers will wish to work collectively. Commodity chains involving higher value crops often have fewer buyers, and this reduces risks of contractual failure vis-à-vis the case with most staple foods. In the case of cotton and tobacco, there are often only a few ginners and tobacco companies with capacity to supply inputs and technical support, and to buy and process the crop; this reduces the 'costs of enforcing agreed behavior' referred to above. In some countries, such as Mozambique, the State zones the procurement of these crops, and this further reduces these costs; such measures are practically unenforceable in the case of staple foods due to the vast number of potential buyers and marketing channels. In Tanzania, coffee producers have had limited choice as to where they have their coffee cured and graded prior to export, and no choice but to export through the auction at Moshi. This narrow marketing channel helps banks in the recovery of production and marketing credit they provide to primary societies, and this in turn renders the primary societies more bankable and viable. Export-based horticulture is another case where there are few buyers. The self-same crops can be sold on the local market, but few buyers have the necessary organization to provide access to premium export markets.

This proposition also implies that it is possible to increase the prospects for success of collective marketing, with staples as with other crops, by maximizing added value per unit of effort and minimizing the hidden costs. Table 2 suggests some ways in which this can be achieved. 
Table 2 - Ways of 'accentuating the positive' in collective marketing

Measure

1. Seek to develop collective marketing among groups with a history of collective Endeavour, e.g. traditional forms of cooperative activity, and Farmer Field Schools such as those in Uganda (Okoth et al. 2006)

2. Focus on simple activities, e.g. bulking, accessing input supplies, joint liability for credits

3. Constitute small primary groups (not more than 30 members)

4. Homogeneous membership, with regard to their interests and objectives

5. Seek out stable relationships with strong trade counter-parties, where these are profitable

6. Training/awareness-raising with members and leaders, especially re attitudes and business skills

7. Combining collective marketing with technical support to production

8. Focus on products offering a higher return to collective effort. In the case of cereals, this may mean producing seed or grain for higher quality/specialist market segments

9. Establish independently managed storage services and warehouse receipt systems which are accessible to producer groups

10. Stronger efforts to enforce the law in case of wrong-doing (e.g. in recent case involving Nakasenyi Adult Literacy Group, Iganga, Uganda)
Such groups tend to have more organizational skills and a higher level of internal discipline and trust, reducing 'hidden costs'

Minimizes complexity of collective decision-making

Allows for more face-to-face interaction, and accountability between members

More difficult for politicians and 'strong men' to assume control

Makes for a more single-minded focus on the group's objectives

Trade counter-party will have an interest in groups' success and survival. A potential disadvantage of such stable relationship is that they expose the group to exploitation by the counter-party. Collective marketers should try to maintain some independence of action. This may involve studying the market, negotiating better terms, and/or seeking expert assistance from federative bodies or NGOs with specialist capabilities.

Increases cohesion of the organization and quality of decision-making

Larger volume and value of produce increases benefits from collective marketing

Makes it easier to recuperate the 'costs' of cooperation

Independent collateral management makes producer groups more bankable and increases their marketing options

Sends out a message that wrong-doing does not pay in projects supporting producer organizations

The first four of items in Table 2 re-emphasize the findings of Stringfellow et al. (1997), who found that successful group enterprises were more likely to have a history of cooperative Endeavour and to be involved in coordinating marketing or procurement activities, rather than more complex 
activities involving the operation of jointly owned assets and in obtaining credit against group guarantees. They also found evidence of successful enterprises being built on patterns of social interaction, notably among women. The fifth item reiterates their observation that group enterprises often worked most effectively under contract with agribusinesses that lock them into the value chain and provide credit, inputs, and markets. However, for reasons discussed earlier, this is often difficult with staple commodities.

The sixth item picks up on the section of this paper dealing with Uganda and on the experience of the Kenya Maize Development Project (KMDP), whose training package is emphasizing 'farming as a business', forward planning of farming and group enterprises, and changing attitudes4 (Coulter 2006). Items 7 to 9 are based on observations throughout the paper, and emphasize the need to maximize the farmers' return to effort spent on cooperative activity. Item 9 picks up on our discussion of coffee curing factories in Tanzania. Primary Societies deposit their coffee with the factories and obtain 'warehouse receipts' which they use to raise marketing credit from a local bank to cover immediate financial needs. The curing company is in effect "collaterally managing" the stock on behalf of the bank, which can easily recover the credit when the primary society sells the product. Indeed, by adding a reputable service provider to the commodity chain, the farmers increase their marketing options and make their primary societies more bankable. It is now the track record of the coffee curing company, rather than the primary society itself, that ensures them access to credit. The last item recalls that the role wider society and the State need to play in stimulating strong cooperative behavior.

The cases examined above suggest that collective approaches are less likely to be successful when they involve dual objectives of food security and surplus disposal, primarily because such initiatives fall short of suggestions in items 3 and 7. Firstly, enterprises collectively marketing staple crops bring together a variety of stakeholder groups with varied interests and have a mix of business and social objectives, which tends to result in slow and weak decision-making. Secondly, as shown by Berg and Kent (1991) spatial and temporal arbitrage tends to be less profitable than promoters envisage, and committee-led entities find it difficult to compete with private traders. At the same

\footnotetext{
${ }^{4}$ The following observation provides some insight as to how attitudes can constrain development. During the author's visit to Kitale district in Kenya, a group member characterized farmers' outlook by saying that people tended to see themselves as failures, had little scope for improving their situation as farmers, and that the only way forward was to get a white collar job. The statement is very significant when one considers that Kitale farmers are privileged among farmers in Kenya with relatively abundant land and good market access (Coulter, 2006).
} 
time we have pointed to alternative approaches which involve greater reliance on individual initiative, including both individual silos and individual storage supported by local microfinance institutions.

Collective marketing is an area where avoidable mistakes are frequently made. For example, the lessons of cereal banks could have been learnt and acted upon in a single decade, whereas in practice they went on being promoted for over three decades in one or other area of Africa. In the case of Tanzania, it should not have been necessary to build 1,000 village stores before discovering they would remain redundant. Those involved with collective marketing should reflect on this and seek to reduce the probability of recurrence.

In the author's experience the problem arises from poverty alleviation and programmatic pressures within the donor community. Budgetary processes provide compelling reasons for donors and NGOs to spend money, and these are often augmented by political and bureaucratic pressures within the host country, placing in an invidious position those officials and consultants who have doubts over the wisdom of the respective expenditures, and whether they will make a lasting contribution to poverty alleviation. In this we share concerns expressed by William Easterly (2006, p.137) that the aid system sometimes pursues contradictory objectives.

Some of the above-mentioned cases show that despite these pressures, project promoters sometimes succeed in devising and implementing imaginative projects and programs with better prospects for sustainability. There is, however, a danger that the current focus on Africa and the frequent advocacy of 'big pushes' to eliminate poverty will lead to more, rather than less, wasteful initiatives, and it is for this reason - rather than any questioning of Africa's need for assistance - that this paper sounds an alarm.

\section{POLICY RECOMMENDATIONS}

Two basic policy recommendations arise from the previous discussion. Firstly, at a practical level, those designing any rural marketing project should analyze the value chain in such a way as to identify activities which best lend themselves to individual initiative, and those where group approaches are more likely to prosper. As a general rule, they will find that dual purpose initiatives involving food security and marketing are more likely to succeed when they rely upon individual initiative, albeit within a framework of micro-credit support.

Single-purpose collective marketing initiatives are most likely to succeed where the cooperation involves significant value addition, which can occur where they complement agricultural intensification and involve bulking substantial quantities of produce for quality-conscious commercial 
buyers. Producer organizations and their promoters can also increase the prospects for success by adopting other measures suggested in Table 2 .

Secondly, donors (bilateral, multilateral, and private) and governments need to find ways of improving the overall quality of agricultural marketing initiatives, particularly those involving collective action. They should seek to do this in a way which does not involve heavy-handed control and leaves players with as much freedom of action as possible. One way of doing this is to establish a system of independent reviews, with the reviewers being contracted by bodies which are completely independent of the agency being evaluated or even the agency financing the initiative concerned. Another would be to institute strict peer-review mechanisms on a country basis. Anybody seeking to implement an agricultural marketing initiative should be required to periodically present the project concerned to assembled peers knowledgeable of the subject in question.

While this may seem like a common sense recommendation, a measure that exposes to public scrutiny the players in the aid and development business will in many cases be forcefully resisted. However, it is worth the pain; it is one measure which will allow us to quickly improve the quality of development assistance, without additional expenditure. It could also build a basis for understanding of what works and what does not. 


\section{REFERENCES}

Bidaux, A., C.A. Barrios, T. Coello, V. Heierli, and R. Ortiz, R. 2002. Programas Regionales de Postcosecha y Fomento (Relata). Informe de Misión de Evaluación. Berne: Swiss Development Cooperation.

Berg, E. and L. Kent. 1991. The economics of cereal banks in the Sahel. Consultancy Report Prepared for USAID. Bethesda, Maryland, USA: Development Alternatives Inc. (DAI).

Bingen, R.J. 1998. Cotton, democracy and development in Mali. Journal of Modern African Studies 36 (2): 265-285.

Chirwa, E., A. Dorward, R, Kachule, I. Kumwenda, J. Kydd, N. Poole, C. Poulton, and M. Stockbridge. 2005. Walking tightropes: Supporting farmer organizations for market access. Natural Resources Perspectives 99. London: ODI.

Coulter, J.P. 2005. Making the transition to a market-based grain marketing system. Paper presented a World Bank/DFID Workshop on Food Price Risk Management (see at http://www.passlivelihoods.org.uk/default.asp?project_id=240\&nc=4921).

Coulter, J.P., D. Burnett, D. J. Walker, and Mukhwana, E. 2000. A feasibility study on the development of a warehouse receipt system in the grain sector for the western region of Kenya. Consultancy report to the World Bank.

Coulter, J.P., J. Brussel, and M. Wright. 1995. Programa Postcosecha en Centroamerica; Evaluación de Impacto y de la Sostenibilidad. Consultancy report prepared for Swiss Development Cooperation, Berne. Published by FAO at: http://www.fao.org/inpho/content/documents//vlibrary/new_else/x5418s/x5418s00.htm

Coulter, J.P. and K.S. Schneider. 2004. Feasibility study of post harvest Project in Mozambique and Tanzania. Consultancy report to the Swiss Agency for Development and Cooperation (SDC)

Coulter, J.P. and A.W. Shepherd. 1995. Inventory credit; An approach to developing agricultural markets. FAO Agricultural Services Bulletin 120: 105

Coulter and Tyler. 1992. Grain market liberalization in Africa; report on Mali case study. Research report for Overseas Development Administration. Mimeo.

Kent, L. 1998) Why cereal banks rarely work: A summary of findings. http://www.foodaid.org/pdfdocs/cmgmt/grainstoragesummary.pdf

Easterly, W. 2006. The white man's burden. Oxford, UK: Oxford University Press

Ferris, S. 2006. Agricultural Marketing and Agro-Processing Support Programme (AMASP). Working Paper, Cali, Colombia: CIAT. Mimeo. 
Fraslin, J-H. 2004. CECAM: A cooperative agricultural financial institution providing credit adapted to farmers'demand in Madagascar. Paving the Way Forward for Rural Finance,' an International Conference on Best Practices. Case Study. Madison, WI: BASIS - Broadening Access and Strengthening Input Market Systems.

Fraslin, J-H. 2005. Une expérience de warrantage à Madagascar. Le crédit Grenier Commun Villageois (GCV) des CECAM (Caisses d'Epargne et de Crédit Mutuels). Paper presented at the Methodological Capitalization Workshop on Inventory Credit, Niamey, February 2-3, 2005 .

Gergely, N., Guillermain and De Lardemelle, L. 1990. Evaluation de Banques de Céréales au Sahel. Rapport de Synthèse. Prepared for FAO, Rome.

Günther D., \& Mück, O., 1995. Les banques des céréales ont-elles fait banqueroutes? GTZ, Eschborn, Germany. Harnisch, R. \& Krall, S., 1986.Isiaho, R. 2005. Smallholder groups portfolio evaluation and recommendations for SO 7. Prepared For USAID Kenya.

Kwadjo, G. T-M. 2000. Inventory credit: A financial product in Ghana. Paper presented at a conference on Advancing Micro-Finance in Rural West Africa, February 22-25, 2000, Bamako, Mali.

Meyer, R.L, R. Roberts, and A. Mugume. 2004. Agricultural finance in Uganda; The way forward. FSD Series No. 13. Financial systems Development Programme. Kampala: GTZ, SIDA.

Okoth, J., A. Braun, R.K. Delve, H. Khamaala, G. Khisa, and J. Thomas. 2006. The emergence of farmer field schools networks in Eastern Africa. Paper presented at Research Workshop on Collective Action and Market Access for Smallholders, October 2 - 5, 2006, Cali, Colombia.

Reusse, E. 2002. Performance of cereal banks in the West African Sahel. Rome: FAO.

Stringfellow, R, J. Coulter, A. Hussain, T. Lucey, and C. McKone. 1997. Improving access of smallholders to agricultural services in Sub-Saharan Africa. Small Enterprise Development $8(3): 35-41$. 


\section{List of CAPRi Working Papers}

01 Property Rights, Collective Action and Technologies for Natural Resource Management: A Conceptual Framework, by Anna Knox, Ruth Meinzen-Dick, and Peter Hazell, October 1998.

02 Assessing the Relationships between Property Rights and Technology Adoption in Smallholder Agriculture: A Review of Issues and Empirical Methods, by Frank Place and Brent Swallow, April 2000.

03 Impact of Land Tenure and Socioeconomic Factors on Mountain Terrace Maintenance in Yemen, by A. Aw-Hassan, M. Alsanabani and A. Bamatraf, July 2000.

04 Land Tenurial Systems and the Adoption of a Mucuna Planted Fallow in the Derived Savannas of West Africa, by Victor M. Manyong and Victorin A. Houndékon, July 2000.

05 Collective Action in Space: Assessing How Collective Action Varies Across an African Landscape, by Brent M. Swallow, Justine Wangila, Woudyalew Mulatu, Onyango Okello, and Nancy McCarthy, July 2000.

06 Land Tenure and the Adoption of Agricultural Technology in Haiti, by Glenn R. Smucker, T. Anderson White, and Michael Bannister, October 2000.

07 Collective Action in Ant Control, by Helle Munk Ravnborg, Ana Milena de la Cruz, María Del Pilar Guerrero, and Olaf Westermann, October 2000.

08 CAPRi Technical Workshop on Watershed Management Institutions: A Summary Paper, by Anna Knox and Subodh Gupta, October 2000.

09 The Role of Tenure in the Management of Trees at the Community Level:

Theoretical and Empirical Analyses from Uganda and Malawi, by Frank Place and Keijiro Otsuka November 2000.

10 Collective Action and the Intensification of Cattle-Feeding Techniques a Village Case Study in Kenya's Coast Province, by Kimberly Swallow, November 2000.

11 Collective Action, Property Rights, and Devolution of Natural Resource Management: Exchange of Knowledge and Implications for Policy, by Anna Knox and Ruth MeinzenDick, January 2001.

12 Land Dispute Resolution in Mozambique: Evidence and Institutions of Agroforestry Technology Adoption, by John Unruh, January 2001. 
13 Between Market Failure, Policy Failure, and "Community Failure": Property Rights, CropLivestock Conflicts and the Adoption of Sustainable Land Use Practices in the Dry Area of Sri Lanka, by Regina Birner and Hasantha Gunaweera, March 2001.

14 Land Inheritance and Schooling in Matrilineal Societies: Evidence from Sumatra, by Agnes Quisumbing and Keijuro Otsuka, May 2001.

15 Tribes, State, and Technology Adoption in Arid Land Management, Syria, by Rae, J, Arab, G., Nordblom, T., Jani, K., and Gintzburger, G., June 2001.

16 The Effects of Scales, Flows, and Filters on Property Rights and Collective Action in Watershed Management, by Brent M. Swallow, Dennis P. Garrity, and Meine van Noordwijk, July 2001.

17 Evaluating Watershed Management Projects, by John Kerr and Kimberly Chung, August 2001.

18 Rethinking Rehabilitation: Socio-Ecology of Tanks and Water Harvesting in Rajasthan, North-West India, by Tushaar Shah and K.V.Raju, September 2001.

19 User Participation in Watershed Management and Research, by Nancy Johnson, Helle Munk Ravnborg, Olaf Westermann, and Kirsten Probst, September 2001.

20 Collective Action for Water Harvesting Irrigation in the Lerman-Chapala Basin, Mexico, by Christopher A. Scott and Paul Silva-Ochoa, October 2001.

21 Land Redistribution, Tenure Insecurity, and Intensity of Production: A Study of Farm Households in Southern Ethiopia, by Stein Holden and Hailu Yohannes, October 2001.

22 Legal Pluralism and Dynamic Property Rights, by Ruth Meinzen-Dick and Rajendra Pradhan, January 2002.

23 International Conference on Policy and Institutional Options for the Management of Rangelands in Dry Areas, by Tidiane Ngaido, Nancy McCarthy, and Monica Di Gregorio, January 2002.

24 Climatic Variablity and Cooperation in Rangeland Management: A Case Study From Niger, by Nancy McCarthy and Jean-Paul Vanderlinden, September 2002.

25 Assessing the Factors Underlying the Differences in Group Performance: Methodological Issues and Empirical Findings from the Highlands of Central Kenya, by Frank Place, Gatarwa Kariuki, Justine Wangila, Patti Kristjanson, Adolf Makauki, and Jessica Ndubi, November 2002. 
The Importance of Social Capital in Colombian Rural Agro-Enterprises, by Nancy Johnson, Ruth Suarez, and Mark Lundy, November 2002.

27 Cooperation, Collective Action and Natural Resources Management in Burkina Faso: A Methodological Note, by Nancy McCarthy, Céline Dutilly-Diané, and Boureima Drabo, December 2002.

28 Understanding, Measuring and Utilizing Social Capital: Clarifying Concepts and Presenting a Field Application from India, by Anirudh Krishna, January 2003.

29 In Pursuit Of Comparable Concepts and Data, about Collective Action, by Amy Poteete And Elinor Ostrom, March 2003.

30 Methods of Consensus Building for Community Based Fisheries Management in Bangladesh and the Mekong Delta, by Parvin Sultana and Paul Thompson, May 2003.

31 Formal and Informal Systems in Support of Farmer Management of Agrobiodiversity: Some Policy Challenges to Consolidate Lessons Learned, by Marie Byström, March 2004.

32 What Do People Bring Into the Game: Experiments in the Field About Cooperation in the Commons, by Juan-Camilo Cárdenas and Elinor Ostrom, June 2004.

33 Methods for Studying Collective Action in Rural Development, by Ruth Meinzen-Dick, Monica Di Gregorio, and Nancy McCarthy, July 2004.

34 The Relationship between Collective Action and Intensification of Livestock Production: The Case of Northeastern Burkina Faso, by Nancy McCarthy, August 2004.

35 The Transformation of Property Rights in Kenya's Maasailand: Triggers and Motivations by Esther Mwangi, January 2005.

36 Farmers' Rights and Protection of Traditional Agricultural Knowledge, by Stephen B. Brush, January 2005.

37 Between Conservationism, Eco-Populism and Developmentalism - Discourses in Biodiversity Policy in Thailand and Indonesia, by Heidi Wittmer and Regina Birner, January 2005.

38 Collective Action for the Conservation of On-Farm Genetic Diversity in a Center of Crop Diversity: An Assessment of the Role of Traditional Farmers' Networks, by Lone B. Badstue, Mauricio R. Bellon, Julien Berthaud, Alejandro Ramírez, Dagoberto Flores, Xóchitl Juárez, and Fabiola Ramírez, May 2005.

39 Institutional Innovations Towards Gender Equity in Agrobiodiversity Management: Collective Action in Kerala, South India,, by Martina Aruna Padmanabhan, June 2005. 

and Biodiversity from Legal Pluralism, by Melanie G. Wiber, July 2005.

41 Who Knows, Who Cares? Determinants of Enactment, Awareness and Compliance with Community Natural Resource Management Bylaws in Uganda, by Ephraim Nkonya, John Pender, Edward Kato, Samuel Mugarura, and James Muwonge, August 2005.

42 Localizing Demand and Supply of Environmental Services: Interactions with Property Rights, Collective Action and the Welfare of the Poor, by Brent Swallow, Ruth MeinzenDick, and Meine von Noordjwik, September 2005.

43 Initiatives for Rural Development through Collective Action: The Case of Household Participation in Group Activities in the Highlands of Central Kenya, By Gatarwa Kariuki and Frank Place, September 2005.

44 Are There Customary Rights to Plants? An Inquiry among the Baganda (Uganda), with Special Attention to Gender, by Patricia L. Howard and Gorettie Nabanoga, October 2005.

45 On Protecting Farmers' New Varieties: New Approaches to Rights on Collective Innovations in Plant Genetic Resources by Rene Salazar, Niels P. Louwaars, and Bert Visser, January 2006.

46 Subdividing the Commons: The Politics of Property Rights Transformation in Kenya's Maasailand, by Esther Mwangi, January 2006.

47 Biting the Bullet: How to Secure Access to Drylands Resources for Multiple Users, by Esther Mwangi and Stephan Dohrn, January 2006.

48 Property Rights and the Management of Animal Genetic Resources, by Simon Anderson and Roberta Centonze, February 2006.

49 From the Conservation of Genetic Diversity to the Promotion of Quality Foodstuff: Can the French Model of 'Appellation d'Origine Contrôlée' be Exported? by Valérie Boisvert, April 2006.

50 Facilitating Collective Action and Enhancing Local Knowledge: A Herbal Medicine Case Study in Talaandig Communities, Philippines, by Herlina Hartanto and Cecil Valmores, April 2006.

51 Water, Women and Local Social Organization in the Western Kenya Highlands, by Elizabeth Were, Brent Swallow, and Jessica Roy, July 2006.

52 The Many Meanings of Collective Action: Lessons on Enhancing Gender Inclusion and Equity in Watershed Management, by Laura German, Hailemichael Taye, Sarah Charamila, Tesema Tolera, and Joseph Tanui, July 2006. 
53 Decentralization and Environmental Conservation: Gender Effects from Participation in Joint Forest Management, by Arun Agrawal, Gautam Yadama, Raul Andrade, and Ajoy Bhattacharya, July 2006.

54 Improving the Effectiveness of Collective Action: Sharing Experiences from Community Forestry in Nepal, by Krishna P. Achyara and Popular Gentle, July 2006.

55 Groups, Networks, and Social Capital in the Philippine Communities, by Marie Godquin and Agnes R. Quisumbing, October 2006.

56 Collective Action in Plant Genetic Resources Management: Gendered Rules of Reputation, Trust and Reciprocity in Kerala, India, by Martina Aruna Padmanabhan, October 2006.

57 Gender and Local Floodplain Management Institutions--A case study from Bangladesh, by Parvin Sultana and Paul Thompson, October 2006.

58 Gender Differences in Mobilization for Collective Action: Case Studies of Villages in Northern Nigeria, by Saratu Abdulwahid, October 2006.

59 Gender, Social Capital and Information Exchange in Rural Uganda, by Enid Katungi, Svetlana Edmeades, and Melinda Smale, October 2006.

60 Rural Institutions and Producer Organizations in Imperfect Markets: Experiences from Producer Marketing Groups in Semi-Arid Eastern Kenya, by Bekele Shiferaw, Gideon Obare and Geoffrey Muricho, November 2006.

61 Women's Collective Action and Sustainable Water Management: Case of SEWA's Water Campaign in Gujarat, India, by Smita Mishra Panda, October 2006.

62 Could Payments for Environmental Services Improve Rangeland Management inCentral Asia, West Asia and North Africa? by Celine Dutilly-Diane, Nancy McCarthy, Francis Turkelboom, Adriana Bruggeman, James Tiedemann, Kenneth Street and Gianluca Serra, January 2007.

63 Empowerment through Technology: Gender Dimensions of Social Capital Build-Up in Maharashtra, India, by Ravula Padmaja and Cynthia Bantilan, February 2007.

64 Gender and Collective Action: A Conceptual Framework for Analysis, by Lauren Pandolfelli, Ruth Meinzen-Dick, and Stephan Dohrn, May 2007.

65 Gender, Wealth, and Participation in Community Groups in Meru Central District, Kenya, by Kristin E. Davis and Martha Negash, May 2007.

66 Beyond Group Ranch Subdivision: Collective Action for Livestock Mobility, Ecological Viability, and Livelihoods, by Shauna BurnSilver and Esther Mwangi, June 2007. 
67 Farmer Organization, Collective Action and Market Access in Meso-America, by Jon Hellin, Mark Lundy, and Madelon Meijer, October 2007.

68 Collective Action for Innovation and Small Farmer Market Access: The Papa Andina Experience, by André Devaux, Claudio Velasco, Gastón López, Thomas Bernet, Miguel Ordinola, Hernán Pico, Graham Thiele, and Douglas Horton, October 2007.

69 Collective Action and Marketing of Underutilized Plant Species: The Case of Minor Millets in Kolli Hills, Tamil Nadu, India, by Guillaume P. Gruère, Latha Nagarajan, and E.D.I. Oliver King, M.S. Swaminathan Research Foundation, October 2007.

70 The Role of Public-Private Partnerships and Collective Action in Ensuring Smallholder Participation in High Value Fruit and Vegetable Supply Chains, by Clare Narrod, Devesh Roy, Julius Okello, Belem Avendaño, Karl Rich, and Amit Thorat, October 2007.

71 Collective Action for Small-Scale Producers of Agricultural Biodiversity Products, by Froukje Kruijssen, Menno Keizer, and Alessandra Giuliani, October 2007. 